\title{
Community-based tourism: Capability and community participation in tourism development
}

\author{
Idris*, A. Purnomo \& M. Rahmawati \\ Universitas Negeri Malang, Malang, Indonesia
}

\begin{abstract}
Community-based tourism (CBT) is a term that has various interpretations, which in its implementation has led to a long debate among scholars and practitioners. Community involvement in tourism development, which is a crucial issue in CBT, is often questionable and often cannot be implemented in reality. Some of the reasons for this include a lack of understanding and practical experience with CBT. This paper aims to discuss the implementation of CBT, particularly as an instructive review of the CBT literature to synthesize key elements regarding the community's capabilities and participation in the development of tourism destinations. Various literatures show that local communities' knowledge and ability in developing tourist destinations is an effective key in supporting the implementation of CBT for sustainable tourism development. In addition, the community's capability to participate in tourism development directly requires the attention of stakeholders and government officials so that it can be a key support for community-based tourism development.
\end{abstract}

Keywords: CBT, capability, community participation, tourism development

\section{INTRODUCTION}

As the idea of sustainable development began to develop in tourism, increasing attention was paid to the issue of involving local communities in destination development policies and planning (Dangi \& Jamal 2016; Dodds et al. 2018; Ernawati et al. 2017). However, many researchers and practitioners still question the value and application of public participation theory despite the developing field. They claim that the theory is too naive and expensive to implement (Kim \& Kang 2020; Lee \& Jan 2019; Lindstrom \& Larson 2016). Part of the problem is that the definition of sustainability in tourism tends to be too general and all-embracing for its practical implementation (Mayaka et al. 2018). Furthermore, the lack of practical actions that promote and test community engagement strategies is also seen as a weakness (Curcija et al. 2019).

Community participation is an integral part of sustainable tourism development, especially in accordance with community-based traditions. In addition, it also highlights the right to be involved in the transformation of a community into a tourist destination and the benefits that may be derived from this involvement (Lindstrom \& Larson 2016). Several attempts have been made to articulate the practical action of community involvement in tourism development. This is often claimed to be an unrealistic and utopian strategy because of its complexity and high transaction costs (Zielinski et al. 2018).

Discussions about CBT have become prominent, including a mixed understanding of what CBT entails and a critical evaluation of the extent to which it is community-oriented (Dangi \& Jamal 2016; Mtapuri \& Giampiccoli 2016; Ruiz-Ballesteros \& Cáceres-Feria 2016). Despite the acceptance of community-based tourism and the involvement of local stakeholders in tourism development in

*Corresponding author: idris.fis@um.ac.id 
theoretical debates, effective implementation is still considered a challenge among scholars, as well as practitioners, in the field (Kala \& Bagri 2018; Manyara \& Jones 2007). Therefore, this article contributes to the debate and implementation of community-based tourism, highlighting the community's participation and capabilities in theoretical tourism destination development.

\section{COMMUNITY PARTICIPATION IN TOURISM}

Participation is defined as a thought or action taken by a person to contribute to achieve common goals and be responsible for the efforts made (Sastropoetro 1986). Sulistiyorini (2015) describes that participation can be defined as participation or participation by individuals or groups, both material and non-material. While community participation in tourism means the involvement of the community in the process of identifying a problem and tourism potential in their environment, selecting solutions in solving problems, implementing in solving problems, and being able to evaluate them are necessary (Ramadhan 2014).

There are three elements of the community concept of participation in tourism, including forms of responsibility, a willingness to contribute to achieving common goals, and a willingness to be involved in groups (Sulistiyorini 2015). Participation should be based on a will and awareness from within itself so that there will be no coercion element. In addition, participation must be carried out with an awareness of the responsibility for what it does to achieve goals in a group (Sastropoetro 1986).

Community participation in tourism, in general, consists of two types, namely the real form participation and abstract form participation (Mayaka et al. 2018). Sastropoetro (1986) describes the concept of community participation in tourism based on its type classified into three dimensions. First, thought participation is the involvement that is given in the form of ideas, ideas, or constructive thinking. Second, energy participation, which is physical participation in order to achieve the success of a plan. Third, material participation is the involvement of a person or group in the form of money, property, or goods to achieve joint efforts.

The participation of local communities in various tourism activities in the surrounding environment brings various benefits, especially in the economic sector (Kala \& Bagri 2018; Lee \& Jan 2019; Purnomo et al. 2020). This benefit is what motivates the community to get involved in tourism. The availability of space that can be managed by the community in the tourism sector results in a diversity of livelihoods (Mtapuri \& Giampiccoli 2016; Ruiz-Ballesteros \& CáceresFeria 2016; Zielinski et al. 2018). Management that is applied by local communities in providing various products or services in tourism activities can continue to develop even without government support. In this context, tourism development is managed based on the interaction between local communities and tourists in providing tourism products or services that can provide experiences in exchanging knowledge (Purnomo et al. 2020; Wahyuningtyas et al. 2020).

Local people who have an easy pattern of imitating the provision of services or tourism products at an early stage (exploration) can lead to competition. However, if they can be managed properly, they will become a strong group or community. The existence of a community can provide benefits from tourism activities obtained by the community. In addition, the community also plays a role in strengthening the carrying capacity of the physical or social environment (Lee \& Jan 2019). Tourism activities can increase the number of local people who are increasingly concerned with the preservation of the physical and social environment around them because they realize that tourism in the surrounding environment has an attraction for tourists. The impact is that local people get benefits that can be used to improve environmental quality. Therefore, at this stage, tourism managers cannot experience significant economic benefits because the economic benefits are prioritized for quality improvement, which aims to increase the number of tourist visits to existing tourist objects (Purnomo et al. 2020; Wahyuningtyas et al. 2020).

In the future, an increase in the number of tourist visits has implications for the efforts made by the manager in developing various attractions. This stage is called the involvement community stage, in which local community involvement emerges because they already understand the benefits 


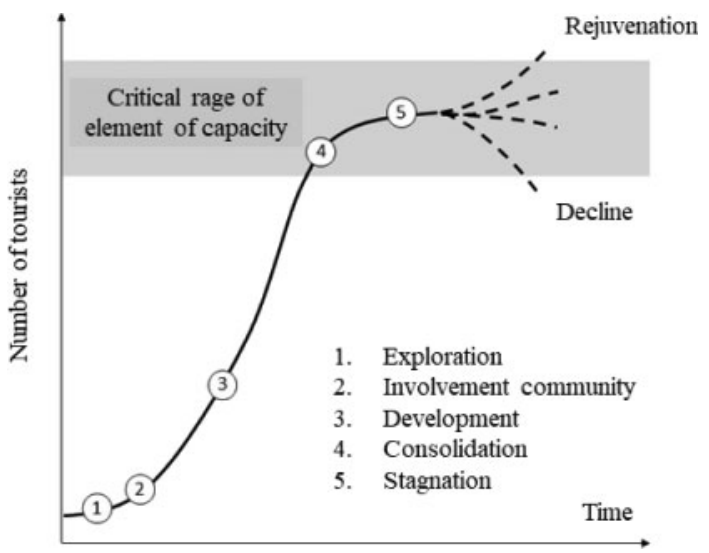

Figure 1. Tourism development stages adapted from Butler (1980).

they get. At this stage, many people build knowledge, both positive and negative, regarding the tourism sector's existence in their surroundings (Butler 1980; Ngo et al. 2018). Positive knowledge is related to the economic benefits that people can feel. Meanwhile, negative public knowledge can be formed from the perceived concern for security, personal life that can be disturbed, or health concern where this can occur when tourists carry infectious diseases while on tourist visits in the surrounding environment. The government has a role in minimizing the occurrence of internal conflicts due to differences in knowledge of local communities (Mayaka et al. 2018). In addition, the government also plays a role as control through regulation or increasing the ability of tourism managers to provide tourism products or services. The regulations that are formed aiming to control any negative impacts from tourism activities must be based on a study of the carrying capacity of the physical and social environment (Lee \& Jan 2019).

\section{COMMUNITY CAPABILITIES IN CBT}

CBT is a local community-based tourism development that acts as a policymaker and receives benefits from the existence of a tourist destination where tourism development will be the basis for sustainable tourism development (Dangi \& Jamal 2016; Okazaki 2008; Razzaq et al. 2012). The essence of sustainable tourism ensures that natural, social, and cultural resources in tourism development can be felt by future generations. Thus, CBT is directed as a form of local community involvement in making decisions for the tourism development process that is able to prosper local communities through the benefits obtained (Mtapuri \& Giampiccoli 2016).

Through CBT, tourism development can stimulate business activities to generate benefits in various fields such as the economic, social, and cultural fields. When tourism can develop properly, the presence of tourism can provide various benefits that can be felt by people involved in tourism activities, including increasing community income through increasing job opportunities. Some of the work opportunities that the community can take advantage of are opening stalls, becoming ticket officers, souvenirs, and other benefits (Dodds et al. 2018; Lee et al. 2013; Lee \& Jan 2019; Pemayun \& Maheswari 2017; Utama 2017). In addition, tourism development will also create infrastructure development that can provide potential access for local people to various facilities (Wulaningrum 2018).

The success of developing a tourist attraction can be determined by support from the government or institutions, good and effective management, and active participation from the community and tourism management groups (Purnomo et al. 2020; Wahyuningtyas et al. 2020). Tourism development through CBT focuses on the involvement of local communities (Amilia et al. 2020). 
This shows that local communities' capability in managing existing tourism is a major factor in whether tourism objects are able to develop or not. Capability is the ability, expertise, competence, and capacity possessed by individuals or groups to manage potential together, solve problems, and design goals to be achieved together (Dodds et al. 2018; Kala \& Bagri 2018; Noho 2014). Community capabilities are assets and attributes that are integrated into society and can be used by them to improve their lives (Bonewati et al. 2017; Manyara \& Jones 2007).

Sofield (2003) explains that CBT is a form of tourism development that has the characteristics of tourism that provides opportunities for local people to be involved in tourism development both in terms of planning and implementing it. In addition, people who are actively involved and passively involved will benefit from this tourism business. In addition, CBT is concerned with planning tourism development based on the needs of local communities so that people can enjoy the benefits (Okazaki 2008). There are three principles in CBT, including local communities' involvement in making decisions, local people getting benefits, and education or assistance for local communities related to tourism. This aims to prepare them to have the ability to manage potential existing destinations (Lee \& Jan 2019).

Local communities have a role as providers of the main components of tourism in its management. This role cannot be separated from their capabilities related to tourism in the surrounding environment. The main features in tourism include attractions, amenities, and accommodation (Inskeep 1991; Kim \& Kang 2020; Pemayun \& Maheswari 2017; Zielinski et al. 2018). Attractions are essential elements that attract tourists (Lee \& Jan 2019). Tourist attractions are related to the concept of what tourists can see and do in a tourist destination (Setyanto 2019). Attractions are significant in attracting tourists to revisit a tourist destination. Tourist attractions at certain destinations usually cannot be imitated by other destinations because each destination has its own characteristics related to its attractions (Curcija et al. 2019; Dangi \& Jamal 2016; Kala \& Bagri 2018). Therefore, an attraction should have uniqueness and characteristics that can distinguish it from other destinations.

The capability of local communities in tourism management can also be seen from the availability of supporting facilities. Supporting facilities are needed to facilitate tourists to enjoy existing tourist attractions. Facilities that must be provided include amenities and accommodation (Lawson 1998). Communities that are capable of various tourism activities provision are one of the crucial components that must be in tourism management (Razzaq et al. 2012). Increasing community capability is one of the driving forces in the development of existing tourism. This shows that in community-based tourism, increasing community capability is vital to manage tourism based on existing potential. In addition, people who are capable of managing tourism can also affect tourist satisfaction during a tour.

Capability building and increasing community participation to be involved in tourism development require awareness of stakeholders and the government's role by providing various training programs, capacity building, and empowerment of tourism conscious communities (Manyara \& Jones 2007). Tourism must be driven by the community, where members of the community are responsible for controlling the tourism infrastructure and facilities available around it (Bonewati et al. 2017; Mayaka et al. 2018). Participation is able to transform people's passive attitudes into responsible and profitable attitudes, inspire entrepreneurial ventures, build partnerships and collaborations, encourage a spirit of cohesiveness, and rejuvenate relationships between communities, tourism destinations, and external stakeholders to increase the prospects for successful and sustainable development (Aref \& Redzuan 2009; Razzaq et al. 2012).

Various studies show that the failure of tourism development is due to low levels of education, unawareness, and limited means of gathering information (Aref \& Redzuan 2009; Kala \& Bagri 2018). Furthermore, poor levels of education, inadequate capacity, unconsciousness, anxious nature of society, and reluctance to take part in the decision-making process are significant obstacles in remote areas of Indonesia (Bonewati et al. 2017). The tourism development authorities' attitude, limited financial resources, poor community capacity, and unavailability of time also hinder community participation in rural destination areas (Ahmeti 2013). Unconsciousness, perceptions of negative aspects of tourism, seasonality, lack of proper training, and entrepreneurial 
skills hinder local people's participation in tourism (Kala \& Bagri 2018). Lack of awareness, general knowledge about tourism, local leadership, entrepreneurial skills, organizational structure, and networks are also some of the common obstacles to effective tourism development (Aref \& Redzuan 2009; Razzaq et al. 2012). A large part of the basis for sustainable bottom-up community development lies in building community capacity. Therefore, community capacities or capabilities must be developed even before a community project or initiative is initiated. Tourism development must be planned in parallel with increasing community capacity (Dangi \& Jamal 2016; Dodds et al. 2018; Mtapuri \& Giampiccoli 2016). In addition, community capacity development emphasizes collaborative, sustainable, and influential processes based on human relations for the development process (Aref \& Redzuan 2009; Kala \& Bagri 2018; Razzaq et al. 2012; Zielinski et al. 2018).

\section{CONCLUSION}

The long debate regarding the concept of CBT and its implications for tourism development, in the end, theoretically and empirically indicate the importance of community knowledge and capabilities to be directly involved in developing tourist destinations. Community participation and the ability to implement their expertise in maintaining, developing, and innovating are the keys to sustainable tourism development. In addition, the role of stakeholders in accommodating and empowering local communities in destination development is another key concern for scholars.

\section{REFERENCES}

Ahmeti, F. 2013. Building Community Capacity for Tourism Development in Transitional Countries: Case of Cossovo. European Journal of Scientific Research, Vol. 115 No. 4, pp. 536-543.

Amilia, W., Rokhani, Prasetya, RC. and Suryadharma, B. 2020. Pembangunan Desa Wisata Gadingan dan Kebutuhan Pengembangan Sumber Daya Manusia dalam Pendekatan Community Based Tourism. JPPM (Jurnal Pengabdian Dan Pemberdayaan Masyarakat), Vol. 4 No. 1, pp. 93-102.

Aref, F. and Redzuan, M.B. 2009. Community Capacity Building for Tourism Development. Journal of Human Ecology, Vol. 27 No. 1, pp. 21-25.

Bonewati, Salman, D. and Barkey, AR. 2017. Peningkatan Kapasitas Masyarakat dalam Pengembangan Pariwisata Berbasis Masyarakat di Desa Olele Kabupaten Bone Bolango. Jurnal Analisis, Vol. 6 No. 2, pp. 139-144.

Butler, RW. 1980. The concept of a tourist area cycle of evolution: Implications for management of resources. The Canadian Geographer, Vol. 24 No. 1, pp. 5-12.

Curcija, M., Breakey, N. and Driml, S. 2019. Development of a conflict management model as a tool for improved project outcomes in community based tourism. Tourism Management, Vol. 70, pp. 341-354.

Dangi, T. and Jamal, T. 2016. An Integrated Approach to 'Sustainable Community-Based Tourism'. Sustainability, Vol. 8 No. 5, p. 475.

Dodds, R., Ali, A. and Galaski, K. 2018. Mobilizing knowledge: determining key elements for success and pitfalls in developing community-based tourism. Current Issues in Tourism, Vol. 21 No. 13, pp. 1547-1568.

Ernawati, N.M., Sanders, D. and Dowling, R. 2017. Host-Guest Orientations of Community-based Tourism Products: A Case Study in Bali, Indonesia. International Journal of Tourism Research, Vol. 19 No. 3, pp. 367-382.

Inskeep, E. 1991. Tourism Planning, Van Nostrand Reinhold, New York.

Kala, D. and Bagri, S.C. 2018. Barriers to local community participation in tourism development: Evidence from mountainous state Uttarakhand, India. Tourism: An International Interdisciplinary Journal, Vol. 66 No. 3, p. 16.

Kim, S. and Kang, Y. 2020. Why do residents in an overtourism destination develop anti-tourist attitudes? An exploration of residents' experience through the lens of the community-based tourism. Asia Pacific Journal of Tourism Research, Vol. 25 No. 8, pp. 858-876.

Lawson. 1998. Tourism and Recreation Handbook of Planning and Design, Architectural Press, London.

Lee, T.H. and Jan, F.-H. 2019. Can community-based tourism contribute to sustainable development? Evidence from residents' perceptions of the sustainability. Tourism Management, Vol. 70, pp. 368-380. 
Lee, T.H., Jan, F.-H. and Yang, C.-C. 2013. Conceptualizing and measuring environmentally responsible behaviors from the perspective of community-based tourists. Tourism Management, Vol. 36, pp. 454-468.

Lindstrom, K.N. and Larson, M. 2016. Community-based tourism in practice: evidence from three coastal communities in Bohuslän, Sweden. Bulletin of Geography. Socio-Economic Series, Vol. 33 No. 33, pp. 71-78.

Manyara, G. and Jones, E. 2007. Best practice model for community capacity-building: A case study of community-based tourism enterprises in Kenya. Tourism: An International Interdisciplinary Journal, Vol. 55 No. 4, p. 13.

Mayaka, M., Croy, W.G. and Cox, J.W. 2018. Participation as motif in community-based tourism: a practice perspective. Journal of Sustainable Tourism, Vol. 26 No. 3, pp. 416-432.

Mtapuri, O. and Giampiccoli, A. 2016. Towards a comprehensive model of community-based tourism development. South African Geographical Journal, Vol. 98 No. 1, pp. 154-168.

Ngo, T., Lohmann, G. and Hales, R. 2018. Collaborative marketing for the sustainable development of community-based tourism enterprises: voices from the field. Journal of Sustainable Tourism, Vol. 26 No. 8, pp. 1325-1343.

Noho, Y. 2014. Kapasitas Pengelolaan Desa Wisata Religius Bongo Kabupaten Gorontalo. Jurnal Nasional Pariwisata, Vol. 6 No. 1, pp. 8-21.

Okazaki, E. 2008. A Community-Based Tourism Model: Its Conception and Use. Journal of Sustainable Tourism, Vol. 16 No. 5, pp. 511-529.

Pemayun, A.A.G.P. and Maheswari, A.A.I.A. 2017. Economic Impacts of Craftsman Statue on Community Based Tourism Development. International Journal of Social Sciences and Humanities (IJSSH), Vol. 1 No. 3, p. 59.

Purnomo, A., Idris, I. and Kurniawan, B. 2020. Understanding local community in managing sustainable tourism at Baluran National Park - Indonesia. GeoJournal of Tourism and Geosites, Vol. 29 No. 2, pp. 508-520.

Ramadhan, F. 2014. Partisipasi Masyarakat dalam Mendukung Kegiatan Pariwisata di Desa Wisata Bejiharjo, Gunungkidul, Yogyakarta. Jurnal Teknik PWK, Vol. 3 No. 4, pp. 949-963.

Razzaq, A.R.A., Mustafa, M.Z., Suradin, A., Hassan, R., Hamzah, A. and Khalifah, Z. 2012. Community Capacity Building for Sustainable Tourism Development. Business and Management Review, Vol. 2 No. 5 , pp. 10-19.

Ruiz-Ballesteros, E. and Cáceres-Feria, R. 2016. Community-building and amenity migration in communitybased tourism development. An approach from southwest Spain. Tourism Management, Vol. 54, pp. 513-523.

Sastropoetro, S. 1986. Partisipasi, Komunitas, Persuasi, Dan Disiplin Dalam Pembangunan Nasional, Alumni, Bandung.

Setyanto, I. 2019. Pengaruh Komponen Destinasi Wisata (4A) Terhadap Kepuasan Pengunjung Pantai Gemah Tulungagung. Jurnal Administrasi Bisnis (JAB), Vol. 72 No. 1, pp. 157-167.

Sofield, T. 2003. Empowerment for Sustainabel Turism Development, Pergamon, Elsevier Science, Oxford.

Sulistiyorini, N.R. 2015. Partisipasi Masyarakat dalam Pengelolaan Sampah di Lingkungan Margaluyu Kelurahan Cicurug. Share Social Work Jurnal, Vol. 5 No. 1, pp. 71-80.

Utama, IG. 2017. Pemasaran Pariwisata, Andi, Yogyakarta.

Wahyuningtyas, N., Kodir, A., Idris, I. and Islam, N. 2020. Accelerating tourism development by community preparedness on disaster risk in Lombok, Indonesia. GeoJournal of Tourism and Geosites, Vol. 29 No. 2 , pp. 545-553.

Wulaningrum, PD. 2018. Pengembangan Kawasan Wisata Berbasis Partisipasi Masyarakat Lokal di Koripan 1 Dlingo. Jurnal BERDIKARI, Vol. 6 No. 2, pp. 131-140.

Zielinski, S., Kim, S., Botero, C. and Yanes, A. 2018. Factors that facilitate and inhibit community-based tourism initiatives in developing countries. Journal Current Issues in Tourism, Vol. 23 No. 6, pp. 723-739. 